\title{
Co-ingestion of carbohydrate and pea protein does not enhance muscle recovery after strenuous exercise
}

\section{A ingestão simultânea de carboidratos e proteina da ervilha não melhora a recuperação muscular} após a realização de exercício extenuante

Leticia Azen Alves COUTINHO ${ }^{1}$

Lucenildo Silva CERQUEIRA²

André Valentim Siqueira RODRIGUES ${ }^{3}$

Cristiana Pedrosa Melo PORTO ${ }^{4}$

Anna Paola Trindade Rocha PIERUCCI ${ }^{4}$

\section{A B S T R A C T}

\section{Objective}

To assess the influence of carbohydrate and added pea protein concentrate supplementation on muscle recovery after a military operation called Leader's Reaction Test.

\section{Methods}

Twenty-four soldiers from the Brazilian Army were divided into three equal groups $(n=8)$. They received either carbohydrate $(0.8 \mathrm{~g} / \mathrm{kg}$ body weight/h), carbohydrate+carbohydrate $(1.0 \mathrm{~g} / \mathrm{kg}$ body weight/h), or carbohydrate+protein $(0.8 \mathrm{~g} / \mathrm{kg}$ body weight/h of carbohydrate $+0.2 \mathrm{~g} / \mathrm{kg}$ body weight $/ \mathrm{h}$ of protein), immediately, 60, and 120 minutes after the Leader's Reaction Test. Prior, immediately after and 24 hours after the Leader's Reaction Test, maximal isometric strength and body composition were assessed. Blood samples were also collected for later analysis of concentrations of lactate dehydrogenase and creatine kinase.

\section{Results}

Twenty-four hours after the Leader's Reaction Test, maximal creatine kinase levels were significantly lower than its levels immediately after (501.00 \pm 422.09 versus $275.29 \pm 242.08 \mathrm{U} / \mathrm{L}$ (carbohydrate); $616.88 \pm 291.45$

${ }^{1}$ Universidade Federal do Rio de Janeiro, Instituto de Nutrição Josué de Castro, Programa de Pós-Graduação em Ciências

Nutricionais. Rio de Janeiro, RJ, Brasil.

2 Universidade Federal do Rio de Janeiro, Instituto Alberto Luiz Coimbra, Programa de Pós-Graduação em Engenharia Biomédica. Rio de Janeiro, RJ, Brasil.

3 Exército Brasileiro, Fortaleza de São João, Instituto de Pesquisa da Capacitação Física do Exército. Rio de Janeiro, RJ, Brasil.

${ }^{4}$ Universidade Federal do Rio de Janeiro, Instituto de Nutrição Josué de Castro, Departamento de Nutrição Básica e Experimental. Av. Carlos Chagas Filho, 373, Bloco J, $2^{\circ}$ andar, Cidade Universitária, Ilha do Fundão, 21941-902, Rio de Janeiro, RJ, Brasil. Correspondência para/Correspondence to: APTR PIERUCCI. E-mail: <pierucci@nutricao.ufrj.br>. 
versus $334.57 \pm 191.61 \mathrm{U} / \mathrm{L}$ (carbohydrate+carbohydrate); and $636.75 \pm 340.67$ versus $382.88 \pm 234.42 \mathrm{U} / \mathrm{L}$ (carbohydrate+protein), $p=0.004)$. The maximal isometric strength and lactate dehydrogenase levels were not significantly different during the time trials.

\section{Conclusion}

The present findings suggest that carbohydrate+protein co-ingestion did not improve the recovery of muscle function nor did it attenuate post-exercise muscle damage markers over carbohydrate alone.

Indexing terms: Creatine kinase. Exercise. L-Lactate dehydrogenase. Supplementary feeding.

\section{R E S U M O}

\section{Objetivo}

Avaliar a influência da suplementação com carboidratos adicionada ao concentrado proteico de ervilha na recuperação muscular, após uma operação militar prática chamada Teste de Reação de Líderes.

\section{Métodos}

Vinte e quatro soldados do Exército Brasileiro foram divididos em três grupos iguais $(n=8)$. Eles receberam a suplementação com carboidrato $(0,8 \mathrm{~g} / \mathrm{kg}$ de peso corporal/h) ou carboidrato mais carboidrato $(1,0 \mathrm{~g} / \mathrm{kg}$ de peso corporal/h) ou carboidrato mais proteína $(0,8 \mathrm{~g} / \mathrm{kg}$ de peso corporal/h de carboidrato + $0.2 \mathrm{~g} / \mathrm{kg}$ de peso corporal/h de proteína), imediatamente, 60 e 120 minutos após o Teste de Reação de Líderes. Avaliaram-se a força isométrica máxima e a composição corporal antes do Teste de Reação de Líderes, imediatamente após e 24 horas após o teste. Amostras de sangue foram coletadas para análise posterior das concentrações de lactato desidrogenase e creatina quinase.

\section{Resultados}

Vinte e quatro horas após o Teste de Reação de Líderes, as concentrações de creatina quinase estavam significativamente reduzidas em comparação ao momento imediatamente posterior $(501.00 \pm 422,09$ versus $275.29 \pm 242.08 \mathrm{U} / \mathrm{L}$ (carboidrato); $616.88 \pm 291,45$ versus $334.57 \pm 191,61 \mathrm{U} / \mathrm{L}$ (carboidrato+carboidrato) e $636.75 \pm 340.67$ versus $382.88 \pm 234,42 \mathrm{U} / \mathrm{L}$ (carboidrato+proteína), $p=0,004$ ). A força isométrica máxima e os níveis de lactato desidrogenase não foram significativamente diferentes em nenhum momento.

\section{Conclusão}

Os resultados sugerem que, em comparação à ingestão do carboidrato isoladamente, a coingestão de carboidrato e proteína não melhora a recuperação da função muscular nem atenua a liberação de marcadores de danos musculares após o exercício.

Termos de indexação: Creatina quinase. Exercício. L-Lactato desidrogenase. Suplementação alimentar.

\section{NTRO D U C T I O N}

Prolonged endurance and short bouts of high intensity exercise are associated with high muscle tissue damage ${ }^{1,2}$ and glycogen depletion ${ }^{3,4}$. High levels of some markers of muscle damage and soreness, such as Creatine Kinase (CK) and Lactate Dehydrogenase (LDH) ${ }^{4}$, are associated with low physical performance ${ }^{5}$, thus exhaustive exercise requires fast recovery. Apparently Carbohydrate (CHO) intake immediately after exercise can promote rapid glycogen repletion and athletes' recovery ${ }^{6}$. However, some researchers have demonstrated that combining Protein (PRO) and $\mathrm{CHO}$ intakes can improve athletes' recovery better than $\mathrm{CHO}$ alone.

Carbohydrate and protein intakes during post-exercise recovery period optimizes glycogen repletion $3,7,8$ and protein balance ${ }^{9}$. Additionally, consumption of $\mathrm{CHO}+\mathrm{PRO}$ or only $\mathrm{CHO}$ supplements after exercise has been associated with lower post-exercise muscle damage markers, such as plasma $\mathrm{CK}^{1,10-14}$ and $\mathrm{LDH}^{11}$, and could also improve muscle function ${ }^{15}$ since it is thought to be one of the best indirect indicators of muscle damage ${ }^{16,17}$. Better muscle function seen after CHO+PRO intake might have practical 
implications for performance in subsequent exercise $^{14,18}$.

However, the literature is controversial since no additional ergogenic effect is promoted by $\mathrm{CHO}+\mathrm{PRO}$ compared with $\mathrm{CHO}$ alone $\mathrm{e}^{18-20}$. Thus, the efficacy of adding PRO to $\mathrm{CHO}$ for endurance performance or recovery remains unclear. The studies that identified the effect of $\mathrm{CHO}+\mathrm{PRO}$ on athletes' recovery used different methodological approaches, which might have contributed to the controversial results in the literature. Studies vary, principally when it comes to study design (cross-over, placebo-controlled performance trial), CHO:PRO ratio, and the source of protein ${ }^{21}$.

The main protein source studied until now is whey $14,18,19,22$. Hence, researches are currently assessing underexploited sources such as alternative protein crops. The functional and bioactive properties of proteins from legume seeds, such as pea (Pisun sativun), have been widely studied because of their importance to novel food development and human health ${ }^{23,24}$. The use of pea protein in the recovery of individuals undergoing exhaustive physical activity is new and could probably bring new contribution to the development of sports supplements.

Special soldiers from the Brazilian Army engaged in a specific field operation experienced a significant increase in blood CK, featuring high muscle damage ${ }^{25}$. This population will probably benefit from nutritional strategies that optimize muscle recovery after an exhaustive physical activity test. Thus, the aim of this study was to assess the influence of a $\mathrm{CHO}+\mathrm{PRO}$ (pea protein concentrate) supplementation on muscle recovery parameters for soldiers undergoing a Leader's Reaction Test (LRT), which is a very exhaustive stage of a military operation designed to prepare military leaders under severe food, water, and sleep deprivation in jungle crossing.

\section{METHODS}

Twenty-three soldiers with a mean \pm Standard Deviation (SD) age of $26.96 \pm 4.14$ years, body mass of $80.74 \pm 9.89 \mathrm{~kg}$, body fat of 10.82 $\pm 3.44 \%$, total body water of $53.43 \pm 6.66 \mathrm{~L}$, and height of $1.78 \pm 0.06 \mathrm{~m}$ concluded the LRT. All participants signed an Informed Consent Form before taking part in the study. The experimental protocol was approved by the Research Ethics Committee of Instituto de Estudos em Saúde Coletiva (IESC, Public Health Research Institute) from Universidade Federal do Rio de Janeiro (UFRJ), Brazil (nº 81/2010).

The study was carried out by means of a double-blind randomized controlled trial. Maximal isometric strength, body composition, and blood samples (for analysis of serum CK and LDH) were assessed in three time Trials: prior (T1), immediately after (T2), and 24 hours post-LRT (T3). At T2 subjects were required to consume one of the three recovery treatments in gel consistency: 1) $\mathrm{CHO}$; 2) $\mathrm{CHO}+\mathrm{CHO}$; and 3 ) $\mathrm{CHO}+\mathrm{PRO}$. All tests were conducted in a fasted state (Figure 1).

The Leader's Reaction Test is a practical military exercise that basically consists of a 100 $\mathrm{km}$ march (sloped roads, fields, and woods), climbs, sprints, and crawls, interspersed with classic military workshops. During those activities the subjects were wearing uniforms and carrying food supplies and weapons, totaling roughly 25 $\mathrm{kg}$. The subjects' energy and water intakes and sleep were restricted and permanently controlled during the four days of LRT, according to Brazilian military doctrine (Table 1).

Body mass and height were determined using the clinical scale-mounted stadiometer Filizola $^{\mathrm{TM}}$ (Brazil), a mechanical model with a maximum weight of $150 \mathrm{~kg}$ and accuracy of 100 $\mathrm{g}$, following the Lohman protoco ${ }^{26}$. Percentage of body fat was assessed using the Lange ${ }^{\mathrm{TM}}$ skinfold caliper and three-site skinfold protocol: abdomen, pectoral, and thigh locations ${ }^{27}$. Total Body Water (TBW) was estimated by tetrapolar bioelectrical impedance using the Biodynamics ${ }^{\mathrm{TM}}$ 310 device.

Maximal isometric force was measured using the hand-held Takei ${ }^{\mathrm{TM}}$ Dynamometer to evaluate muscle function bilaterally. The subjects 
Only individuals who reach and complete the stage of Leader Reaction Test where eligible and randomized to participate $(n=23)$

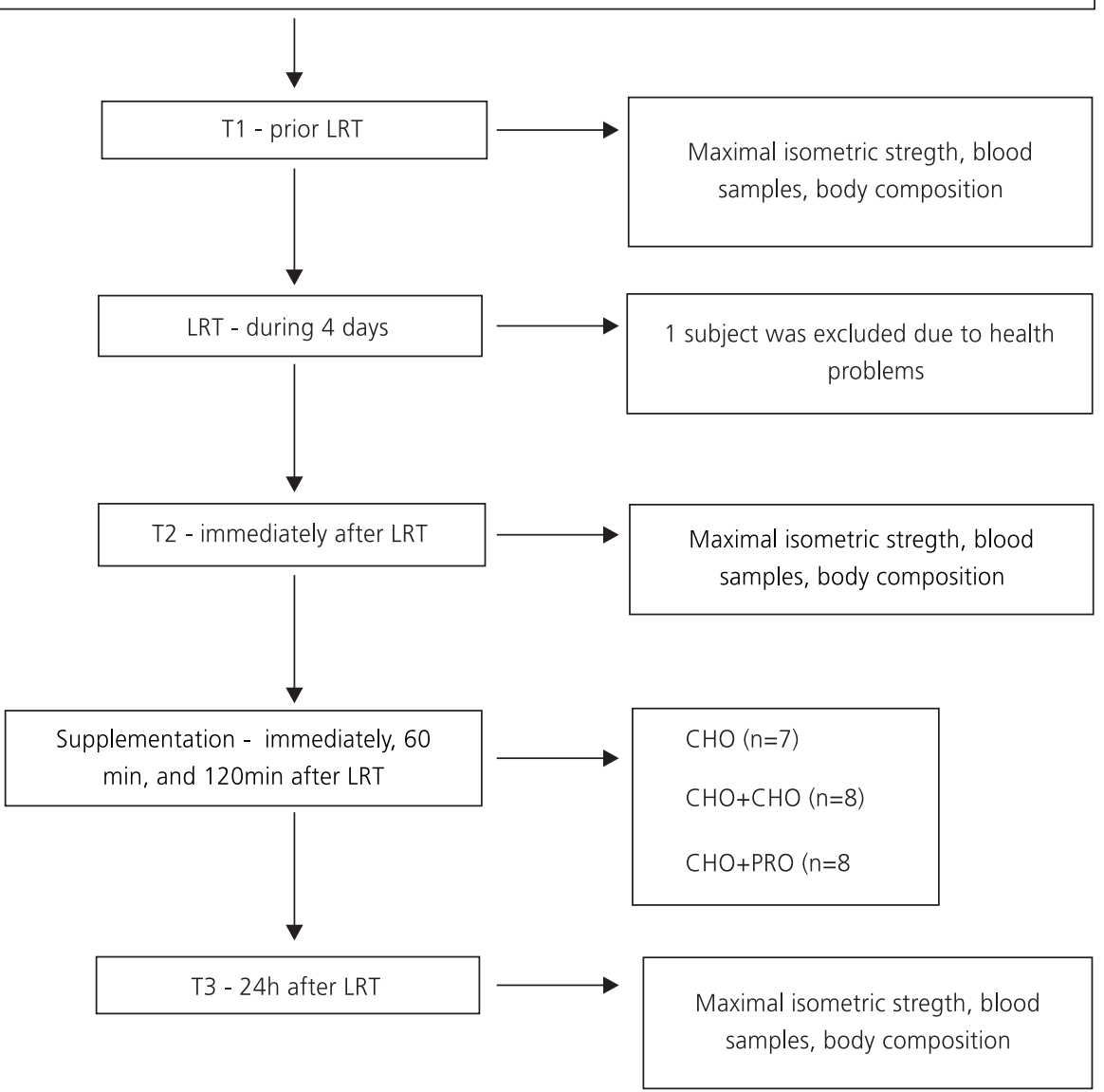

Figure 1. Experimental Design.

Note: T1 (Time Trial 1): Prior LRT (Leader's Reaction Test); T2: Immediately after LRT; T3: 24 hours post - LRT; CHO: Carbohydrate; PRO: Protein.

Table 1. Description of sleep, distance, hydration, and daily energy intake during LRT. Rio de Janeiro (RJ), Brazil, 2010.

\begin{tabular}{lcccc}
\hline Period (day) & Sleep $(\mathrm{h})$ & Distance $(\mathrm{km})$ & Hydration $(\mathrm{L})$ & Daily energy intake $(\mathrm{kcal})$ \\
\hline $1^{\text {st }}$ & 4 & 20 & 3 & 1.737 \\
$2^{\text {nd }}$ & 3 & 36 & 2 & 1.190 \\
$3^{\text {nd }}$ & 2 & 28 & 1 & 970 \\
$4^{\text {nd }}$ & 1 & 16 & - & - \\
\hline
\end{tabular}

Note: LRT: Leader Reaction Test.

exerted a maximal force on the dynamometer, making three attempts for each hand, alternating every 30 seconds, according to Johnson \& Nelson ${ }^{28}$.

In each time Trial (T1, $\mathrm{T} 2$, and $\mathrm{T} 3)$, a 10 $\mathrm{mL}$ blood sample was collected from the antecubital vein and centrifuged at $7000 \mathrm{rpm}$ during 10 minutes for the extraction of blood plasma and further analysis. All plasma samples were stored at $-80^{\circ} \mathrm{C}$. Enzymatic analysis of $\mathrm{LDH}$ and CK concentration was conducted by the semiautomatic Express Plus 550 ${ }^{\mathrm{TM}}$ analyzer.

\section{Supplementation}

The carbohydrate supplement provided subjects with $0.8 \mathrm{~g} / \mathrm{kg}$ body weight $/ \mathrm{h}$; the 
$\mathrm{CHO}+\mathrm{CHO}$ provided the amount of $\mathrm{CHO}$ and more $0.2 \mathrm{~g}$ carbohydrate/ $\mathrm{kg}$ body weight $/ \mathrm{h}$, making the total of $1.0 \mathrm{~g}$ carbohydrate $/ \mathrm{kg}$ body weight $/ \mathrm{h}$; and $\mathrm{CHO}+\mathrm{PRO}$ provided $0.8 \mathrm{~g} / \mathrm{kg}$ body weight $/ \mathrm{h}$ of carbohydrate, and $0.2 \mathrm{~g}$ protein $/ \mathrm{kg}$ body weight/h. The supplementation was provided twice, in the first and in the second hour after LRT, without consuming anything else during this interval. $\mathrm{CHO}$ and $\mathrm{CHO}+\mathrm{PRO}$ contained the same amounts of carbohydrates. $\mathrm{CHO}+\mathrm{CHO}$ and $\mathrm{CHO}+\mathrm{PRO}$ were isocaloric, and all the supplements were designed to have the same physical aspect.

All the supplementation provided identical types of carbohydrate in the form of maltodextrin (50\%) (Corn Brazil, MOR-REX 1910), glucose (35\%) (Corn Brazil, MOR-REX 1940) and fructose (15\%) and Pea Protein Concentrate (PPC) (Propulse Parrheim Foods, Canada) in the $\mathrm{CHO}+\mathrm{PRO}$ supplement. According to the manufacturer's label, the pea protein concentrate has the following proximate concentration of essential amino acids ( $\mathrm{g} / 100 \mathrm{~g}$ of protein): lysine (7.2); phenylalanine (5.5); threonine (3.9); methionine (1.1); tryptophan (1.0); leucine (8.4); isoleucine (4.5); valine (5.0); the last three are also branched-chain amino acids.

The subjects had their meals at the same place and time, since they were confined in the same military base. Food intake for breakfast, lunch, and dinner was controlled, although they were allowed to have two free snacks. Each subject answered a 24-hour Dietary Recall (24HDR) in T3 to quantify energy and macronutrient intakes after the LRT during the 24 hours interval between $\mathrm{T} 2$ and T3. The results were given by the DietPro ${ }^{\mathrm{TM}}$ 5.1i Professional software.

Descriptive statistics are presented as mean \pm SD and in figures as mean \pm Standard Error of the Mean (SEM). All variables were investigated using separate two-way Analysis of Variance (Anova) (time: $\mathrm{T} 1, \mathrm{~T} 2$, and $\mathrm{T} 3$; $\mathrm{x}$ group: $\mathrm{CHO}$, $\mathrm{CHO}+\mathrm{CHO}$, and $\mathrm{CHO}+\mathrm{PRO}$ ) with repeated measures on time, with Tukey post hoc analyses. The evolution of body mass, TBW, and body fat through time trials were taken as percentage of the values in $\mathrm{T} 1$.

All statistical analyses were performed by the Statistical Package for the Social Sciences (SPSS) $^{\mathrm{TM}}$ Version 20.0, with a significance level of $p<0.05$.

\section{RE S U L T S}

\section{Body Composition}

Twenty-three subjects completed all the tests in this study. The body mass, TBW, and body fat recorded during the LRT are demonstrated in Figure 2. For body mass, there were no significant differences between treatments $(p=0.227)$ and interactions for treatments $x$ time $(p=0.161)$. However, the main effect was only observed for time ( $p=0.038)$. There were significant statistical differences for T1 versus T2 $(p=0.020)$, and T1 versus T3 ( $p=0.035)$ (Figure $2 A)$. Statistically, the TBW was not significantly different between treatments $(p=0.664)$ and interactions for treatments versus time $(p=0.881)$. However, Anova indicated a statistically significant main effect for time $(p<0.001)$. There were statistically significant differences for $\mathrm{T} 1$ versus $\mathrm{T} 2$ $(p<0.0001)$, and T1 versus T3 $(p<0.0001)$ (Figure $2 B)$. In relation to body fat, there were no significant statistical differences between treatments $(p=0.068)$ and interactions for treatments versus time $(p=0.562)$. However, Anova indicated a statistically significant main effect for time $(p<0.001)$. There were statistically significant differences for T1 versus T2 $(p<0.0001)$, and T2 versus T3 $(p<0.0001)$ (Figure $2 C$ ).

\section{Maximal isometric force}

The Maximal Isometric Force of the subjects, measured by means of dynamometry, was in average $35.58 \pm 6.28 \mathrm{kgf}$, and it was not significantly different during time trials. 

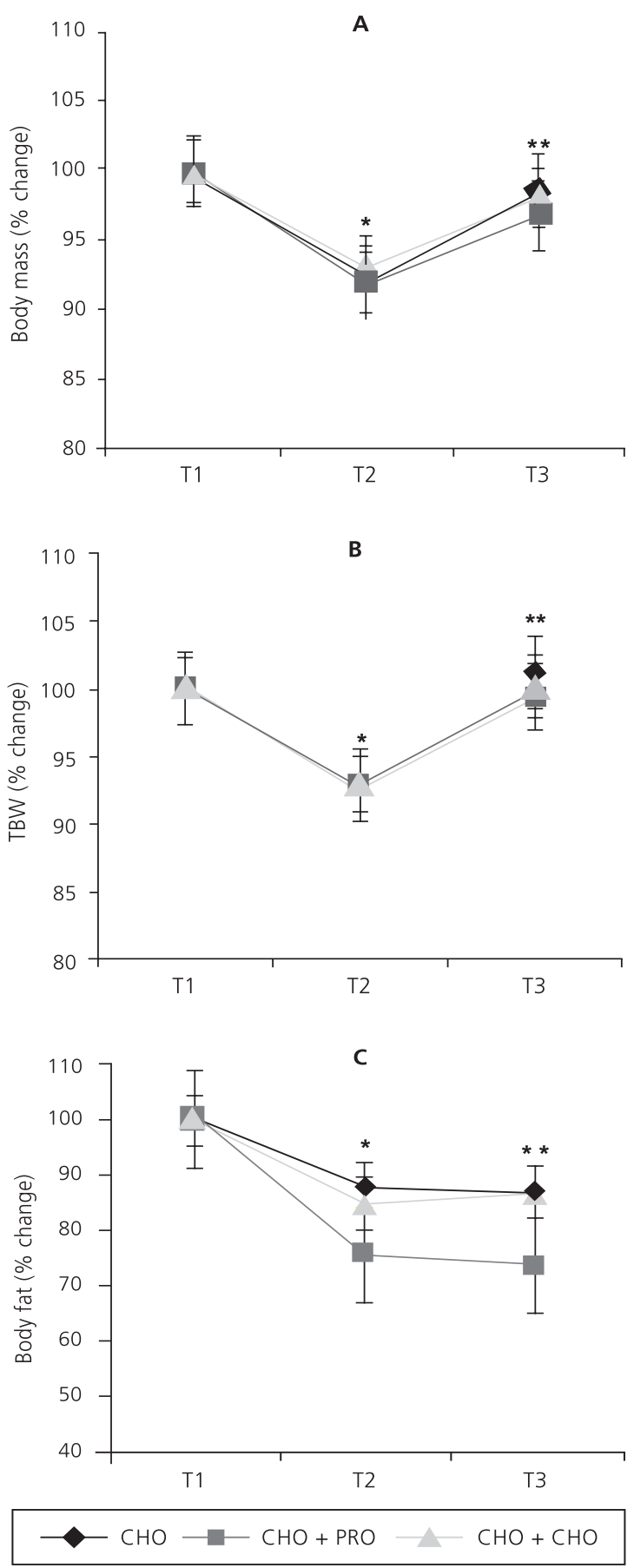

Figure 2. Body mass (A), Total Body Water (TBW) (B), and body fat (C), Mean ( \pm standard error of the mean), through time trials, as percentage of the values in T1. Brazilian Army, Center of Special Operations, Rio de Janeiro (RJ), Brazil.

Note: *Significant difference between T1 versus T2 $(p=0.020(\mathrm{~A})$; $p<0.0001$ (B); $p<0.0001(C) ;{ }^{*}$ Significant difference between $\mathrm{T} 1$ versus T3 $(p=0.035(\mathrm{~A}) ; p<0.0001$ (B); $p<0.0001(\mathrm{C})$

CHO: Carbohydrate; PRO: Protein; T1 (Time Trial 1): Prior LRT (Leader's Reaction Test); T2: Immediately after LRT; T3: 24 hours post-LRT.

\section{Blood analysis}

The subjects' plasma LDH levels varied from 213.00 to $820.00 \mathrm{U} / \mathrm{L}$ and statistical analysis showed that the treatments $(p=0.394)$ or time course $(p=0.125)$ did not differ. The plasma CK levels of the subjects at the beginning of the study varied from 104.00 to $1139.00 \mathrm{U} / \mathrm{L}$. As demonstrated in Figure 3, CK data were statistically different in all time trials, indicating that there was an increase in $\mathrm{T} 2$ and a decrease in T3 $(p=0.004)$, regardless of supplementation (Figure 3).

\section{Food intake after the LRT}

The 24-hour dietary recall administered in T3 demonstrated that there was no difference among groups in terms of energy and macronutrient intakes as shown in Table 2.

In general, free snacks have contributed with $33 \%$ of the total energy consumed. The other controlled meals have contributed with the remainder energy (22\% at breakfast, 30\% at lunch, and $15 \%$ at dinner).

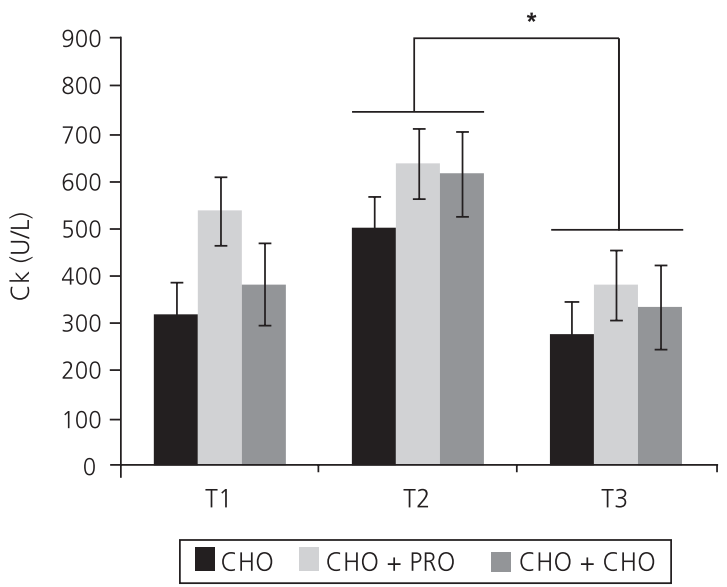

Figure 3. Creatine kinase levels (U/L), Mean ( \pm standard error of the mean), through time trials. Brazilian Army, Center of Special Operations, Rio de Janeiro (RJ), Brazil.

Note: ${ }^{*}$ Significant difference between T2 versus T3 $(p=0.004)$.

CHO: Carbohydrate; PRO: Protein; T1 (Time trial 1): Before LRT; T2: Immediately after LRT (Leader's Reaction Test); T3: 24 hours after-LRT. 
Table 2. Energy and macronutrients intake after LRT, Mean \pm Standard Deviation. Rio de Janeiro (RJ), Brazil, 2010.

\begin{tabular}{|c|c|c|c|c|c|c|c|c|}
\hline & \multicolumn{2}{|c|}{ Total Group $(n=23)$} & \multicolumn{2}{|c|}{ CHO Group $(n=7)$} & \multicolumn{2}{|c|}{$\mathrm{CHO}+\mathrm{CHO}$ Group $(\mathrm{n}=8)$} & \multicolumn{2}{|c|}{$\mathrm{CHO}+\mathrm{PRO}$ Group $(\mathrm{n}=8)$} \\
\hline & $M$ & SD & $M$ & SD & $M$ & SD & M & SD \\
\hline Total energy (kcal) & $6,034.60$ & $\pm 1,272.56$ & $5,522.77 \pm$ & 936.58 & $6,176.56 \pm$ & $1,297.30$ & $6,340.49$ & $\pm 1,504.26$ \\
\hline Carbohydrate (g) & $1,061.52$ & 207.86 & $967.69 \pm$ & 131.51 & $1,119.60 \pm$ & 205.46 & $1,132.28$ & 271.65 \\
\hline Protein (g) & 140.58 & 19.35 & $135.58 \pm$ & 21.33 & $142.23 \pm$ & 21.87 & 143.31 & 16.47 \\
\hline Lipid (g) & 136.24 & 45.33 & $123.30 \pm$ & 39.02 & $139.51 \pm$ & 55.70 & 152.60 & 46.97 \\
\hline
\end{tabular}

Note: Statistical differences were not observed between groups ( $p>0.05)$.

CHO: Carbohydrate; PRO: Protein; M: Mean; SD: Standard Deviation; LRT: Leader Reaction Test.

\section{DISCUSSION}

The primary objective of this study was to examine whether acute ingestion of $\mathrm{CHO}$ along with pea protein supplement, as opposed to $\mathrm{CHO}$ alone, over two hours following strenuous military practical exercise would have an impact on systemic indices of muscle damage and alterations in muscle function.

Recovery of muscle function and exercise performance are important for soldiers who are often taking part in military operations involving severe physical activities performed until exhaustion. Muscle recovery can be evaluated by several parameters such as plasma LDH and CK or even isometric strength, all investigated in this study, concerning the influence of the different types of supplementation administered immediately after the exercise period. According to previous studies, CK and LDH measurements in 24-hour post-exercise have a practical relevance ${ }^{13,22}$ providing basis for the use of such analysis in this work.

The present results demonstrated that $\mathrm{CHO}+\mathrm{PRO}$ intake did not improve any of the measured markers of post-exercise recovery when compared with $\mathrm{CHO}$, regardless of the dose, corroborating many others studies ${ }^{18-20,22}$. Additionally, in accordance to our study, White et al. ${ }^{2}$, Breen et al. ${ }^{18}$, Betts et al. ${ }^{19}$, and Green et al. ${ }^{20}$ showed that the co-ingestion of $\mathrm{CHO}$ and PRO does not improve the recovery of isometric force.

On the other hand, controversial results have been found in the literature, since in many other studies ergogenic effect was promoted by
$\mathrm{CHO}+\mathrm{PRO}$ in the reduction of plasma $\mathrm{CK}^{1,10-14}$ and $\mathrm{LDH}^{11}$ when compared with the ingestion of $\mathrm{CHO}$ alone. Koopman et al. ${ }^{9}$ and Miller et al..$^{29}$ reported that $\mathrm{CHO}+\mathrm{PRO}$ ingestion could improve the balance between protein degradation and protein synthesis, which might explain reductions in muscle damage as per $\mathrm{CHO}+\mathrm{PRO}$ ingestion demonstrated in those studies. According to Breen et al. ${ }^{18}$, it would seem that studying direct markers of sarcolemmal disruption (biopsy or magnetic resonance imaging techniques) in concert with post-exercise tests of muscle function may provide clearer answers regarding the efficacy of $\mathrm{CHO}+\mathrm{PRO}$ to improve recovery.

Many other controversial results are found in the literature. Ivy et al. ${ }^{30}$ discussed some methodological variances that could explain these inconsistencies, including differences in carbohydrate and protein concentrations in supplements, supplement administration protocols, time period of recovery measurements, and applied exercise protocols. Since this is the first study to investigate, in practice, the effect of $\mathrm{CHO}$ supplementation along with pea protein by means of the LRT, comparisons with other findings are limited.

Not only did this study test the effects of two different $\mathrm{CHO}$ concentrations but also the impact of adding protein to a standardized energy supplement. According to Saunders et al. ${ }^{1}$, by matching a carbohydrate portion, differences in recovery can be attributed to anything other than the absolute carbohydrate content of the supplements. So, a limitation from many studies is that the increased availability of total calories 
from the $\mathrm{CHO}+\mathrm{PRO}$ supplementation may have contributed to differences between trials $\mathrm{s}^{1,10,12}$. Apparently, when total calories are controlled, the proposed beneficial effects of the added protein are not fully supported ${ }^{20}$. It is unclear from some studies, however, whether benefits were the result of supplements consumed during exercises ${ }^{14,18}$, post-exercises ${ }^{10,20,22}$ or both ${ }^{11,12,19}$. Ludden et al. ${ }^{10}$ provided evidence that significant attenuation in plasma CK can be achieved with only postexercise feedings of $\mathrm{CHO}+\mathrm{PRO}$. Green et al. ${ }^{20}$ and Millard-Stafford et al. ${ }^{22}$ also compared the effects of post-exercise ingestion of $\mathrm{CHO}+\mathrm{PRO}$ and only $\mathrm{CHO}$ supplementation on muscle damage prevention but neither confirmed the theory proposed by Ludden et al. ${ }^{10}$, regarding CK indices.

It should be noted that $\mathrm{CHO}+\mathrm{PRO}$ group received a 4:1 ratio of carbohydrate to protein supplementation as it has already been tested in other studies $1,7,11,12,14,20,22,31,32$. However, more recent studies have tested the 3:1 ratio, i.e., a larger amount of PRO in relation to $\mathrm{CHO}^{18,19,33,34}$. Therefore, the optimal protein concentration must be clarified so that we can better understand if the result obtained in this study could also be related to this variable.

Another possible explanation for the inconsistent findings in this area might be related to the important response of certain systemic indexes of muscle damage. That is because most studies showing significant effects have maximum CK levels between 250 and $600 \mathrm{U} / \mathrm{L}^{10,11,14,35}$, while those showing no significant effects have typically reported peak CK levels in the 1000-1400 U/L region ${ }^{2,20}$. Considering that the subjects in the present study already had high plasma CK before the LRT, it is reasonable to suppose that our results could have been influenced by this fact, which makes comparison particularly difficult since in other studies subjects usually had normal CK before performing physical tests.

The exercise protocol used for testing the effects of supplementation could also influence the results of the study. Currell \& Jeukendrup ${ }^{36}$ highlighted the fact that the ecological validity of laboratory exhaustive exercise protocols is limited because athletes do not compete in events that require a continued fixed output for as long as possible. The study field activities are performed in real training conditions, under environmental variables that might require higher physical effort and cause generalized body soreness, differently from that experienced in the laboratory exercise protocol used by many studies. Betts et al..$^{19}$ and Green et al. ${ }^{20}$ also adopted field exercise protocol and their reported results corroborate ours, suggesting that the additional protein in the supplement does not benefit muscle recovery in such conditions. When performance is measured in an uncontrolled environment, additional protein does not seem to be advantageous ${ }^{18}$. Most likely, due to that fact, the effects of a $\mathrm{CHO}$ supplement combined with PRO failed to demonstrate the effects on CK and LDH in the present study, even when administered after a military practical activity well-known for its high physical stress and demand.

Although diet had not been fully controlled in our study, the 24HDR showed that the military personnel consumed more energy in the recovery period than they required, and the groups did not differ. The impossibility to fully control the diet could mask the effects of supplementation, but this issue still needs to be clarified, considering that only few studies had standardized the individual's diet according to the subjects eating habits throughout the study (no significant differences in calories, protein, or carbohydrate content of diets during treatment periods $)^{10,11,18,19,35}$. Breen et al. ${ }^{18}$ did not find effects of the $\mathrm{CHO}+\mathrm{PRO}$ supplementation on muscle recovery parameters, but Ludden et al. ${ }^{10}$ and Romano-Ely et al. ${ }^{11}$ have found that the $\mathrm{CHO}+\mathrm{PRO}$ attenuated post-exercise muscle damage, when compared with $\mathrm{CHO}$ supplementation. The comparison between those studies turns out to be difficult since only Breen et al. ${ }^{18}$ demonstrated dietary composition.

Finally, many studies have shown that consuming protein after strength training 
promotes greater growth of lean tissue mass. However, when comparing the effects of soy with milk, some authors have found that animal protein is better ${ }^{37,38}$. Therefore, the different benefits or effects between animal and vegetable proteins on muscle function recovery should be investigated to better understand whether the tested vegetable protein (pea protein concentrate) could generate the same results as whey protein, since this is the most common protein source added to CHO supplements ${ }^{1,10,11,14,18-20,22}$.

\section{CONCLUSION}

In conclusion, when supplementary energy intake is controlled, and $\mathrm{CHO}$ is ingested at rates which are considered optimal for recovery, the addition of pea protein concentrate in the first two hours after field exercise does not seem to improve either the 24-hour recovery of muscle function or post-exercise muscle damage markers better than $\mathrm{CHO}$ alone. In accordance with previous studies, the metabolic and physiological responses to $\mathrm{CHO}+\mathrm{PRO}$ supplementation may depend on the magnitude of CK increase, the $\mathrm{CHO}$ PRO ratio, the exercise protocol, and the type of protein used. Moreover, it is important to evaluate recovery under strict diet control throughout the research period.

\section{ACKNOWLEDGMENTS}

The authors would like to thank Fundação de Amparo à Pesquisa do Estado do Rio de Janeiro and Conselho Nacional de Desenvolvimento Científico e Tecnológico for financial support and budget.

\section{CONTRIBUTORS}

LAA COUTINHO main executor of the intervention. LS CERQUEIRA statistical analyses and manuscript review. AVS RODRIGUES recruitment of subjects, data collection, and manuscript review. CPM PORTO coordinator of activities: data collection, writing, and manuscript review. APTR PIERUCCI data collection, writing, and manuscript review.

\section{REFEREN CES}

1. Saunders MJ, Kane MD, Todd K. Effects of a carbohydrate-protein beverage on cycling endurance and muscle damage. Med Sci Sports Exerc. 2004; 36(7):1233-8. doi: 10.1249/01.MS S.0000132377.66177.9F

2. White JP, Wilson JM, Austin KA, Greer BK, John NSt, Panton LB. Effect of carbohydrate-protein supplement timing on acute exercise-induced muscle damage. J Int Soc Sports Nutr. 2008; 5(5): 1-7. doi: 10.1186/1550-2783-5-5

3. Berardi JM, Price TB, Noreen EE, Lemon PW. Post-exercise muscle glycogen recovery enhanced with a carbohydrate-protein supplement. Med Sci Sports Exerc. 2006; 38(6):1106-13.

4. Van Loon LJC, Saris WHM, Kruijshoop M, Wagenmakers JM. Maximizing postexercise muscle glycogen synthesis: Carbohydrate supplementation and the application of amino acid or protein hydrolysate mixtures. Am J Clin Nutr. 2000; 72(1):106-11.

5. Nosaka K, Sacco P, Mawatari K. Effects of amino acid supplementation on muscle soreness and damage. Int J Sport Nutr Exerc Metab. 2006; 16(6):620-35.

6. Jentjens $R$, Jeukendrup $A E$. Determinants of post-exercise glycogen synthesis during short-term recovery. Sports Med. 2003; 33(2):117-44. doi: 10.2165/00007256-200333020-00004

7. Williams MB, Raven PB, Fogt DL, Ivy JL. Effects of recovery beverages on glycogen restoration and endurance exercise performance. J Strength Cond Res. 2003; 17(1):12-9.

8. Zawadzki KM, Yaspelkis III BB, Ivy JL. Carbohydrateprotein complex increases the rate of muscle glycogen storage after exercise. J Appl Physiol. 1992; 72(5):1854-9.

9. Koopman R, Pannemans DLE, Jeukendrup AE, Gijsen AP, Senden JMG, Halliday D, et al. Combined ingestion of protein and carbohydrate improves protein balance during ultra-endurance exercise. Am J Physiol Endocrinol Metab. 2004; 287(4):E712-20. doi: 10.1152/ajpendo.00543.2003

10. Ludden ND, Saunders MJ, Todd MK. Post-exercise carbohydrate-protein-antioxidant ingestion decreases plasma creatine kinase and muscle soreness. Int J Sport Nutr Exerc Metab. 2007: 17(1):109-23.

11. Romano-Ely BC, Todd MK, Saunders MJ, Laurent TSt. Effect of an isocaloric carbohydrate-proteinantioxidant drink on cycling performance. Med Sci Sports Exerc. 2006; 38(9):1608-16. doi: 10.1249/ 01.mss.0000229458.11452.e9 
12. Saunders MJ, Moore RW, Kies AK, Ludden ND, Pratt CA. Carbohydrate and protein hydrolysate coingestion's improvement of late-exercise time trial performance. Int J Sport Nutr Exerc Metab. 2009; 19(2):136-49.

13. Skillen RA, Testa M, Applegate, EA, Heiden EA, Fascetti AJ, Casazza GA. Effects of an amino acid-carbohydrate drink on exercise performance after consecutive-day exercise bouts. Int J Sport Nutr Exerc Metab. 2009; 18(5):473-92.

14. Valentine RJ, Saunders MJ, Todd MK, Laurent TG St. Influence of carbohydrate-protein beverage on cycling endurance and indices of muscle disruption. Int J Sport Nutr Exerc Metab. 2008; 18(4):363-78.

15. Cockburn E, Hayes HR, French DN, Stevenson E, St Clair Gibson A. Acute milk-based protein- $\mathrm{CHO}$ supplementation attenuates exercise-induced muscle damage. Appl Physiol Nutr Metab. 2008; 33(4):775-83. doi: 10.1139/H08-057

16. Clarkson PM, Hubal MJ. Exercise-induced muscle damage in humans. Am J Phys Med Rehab. 2002; 81(11Suppl):S52-69. doi: 10.1097/01.PHM.0000 029772.45258 .43

17. Warren GL, Ingalls CP, Lowe D A, Armstrong RB. What mechanisms contribute to the strength loss that occurs during and in the recovery from skeletal muscle injury? J Orthop Sports Phys Ther. 2002; 32(2):58-64.

18. Breen L, Tipton KD, Jeukendrup AE. No effect of carbohydrate-protein on cycling performance and indices of recovery. Med Sci Sports Exerc. 2010; 42(6):1140-8. doi: 10.1249/MSS.0b013e3181c $91 \mathrm{f1a}$

19. Betts JA, Toone RJ, Stokes KA, Thompson D. Systemic indices of skeletal muscle damage and recovery of muscle function after exercise: Effect of combined carbohydrate-protein ingestion. Appl Physiol Nutr Metab. 2009; 34(4):773-84. doi: 10.1139/H09-070

20. Green MS, Corona BT, Doyle JA, Ingalls CP. Carbohydrate-Protein drinks do not enhance recovery from exercise-induced muscle injury. Int J Sport Nutr Exerc Metab. 2008; 18(1):1-18.

21. Alves LA, Pierucci AP. Influência da ingestão de bebidas contendo carboidrato e proteína sobre a performance e a recuperação muscular pós-exercício de endurance. Rev Educ Fis. 2008; (141):35-44.

22. Millard-Stafford M, Warren GL, Thomas LM, Doyle JA, Snow T, Hitchcock K. Recovery from run training: Efficacy of a carbohydrate-protein beverage? Int J Sport Nutr Exerc Metab. 2005; 15(6):610-24.
23. Pereira HVR, Saraiva KP, Carvalho LMJ, Andrade LR, Pedrosa C, Pierucci APRT. Legumes seeds protein isolates in the production of ascorbic acid microparticles. Food Res Int. 2009; 42(1):115-21. doi: 10.1016/j.foodres.2008.10.008

24. Rangel A, Saraiva K, Schwengber P, Narciso MS, Domont GB, Ferreira ST, et al. Biological evaluation of a protein isolate from cowpea (Vigna unguiculata) seeds. Food Chem. 2004; 87(4):491-9. doi: 10.1016/j.foodchem.2003.12.023

25. Rodrigues AVS, Martinez EC, Alves LA, Pitaluga Filho MV, Pinto FGF, Lima ES, et al. Muscular stress in soldiers of the brazilian army supplemented with $\mathrm{CHO}$ and $\mathrm{BCAA}$ during operations. $54^{\text {th }}$ American College of Sports Medicine. New Orleans, Louisiana. Med Sci Sport Exerc. 2007; 39(5):205S.

26. Lohman TG, Roche AF, Martorell R. Anthropometric standardization reference manual. Champaign (IL): Human Kinetics; 1988.

27. Jackson AS, Pollock ML. Generalized equations for predicting body density for men. Br J Nutr. 1978; 40(3):497-504.

28. Johnson BL, Nelson JK. Practical measurements for evaluation in physical education. $3^{\text {nd }}$ ed. Minneapolis (MN): Burgess Publish Company; 1979.

29. Miller SL, Maresh CM, Armstrong LE, Ebbeling CB, Lennon S, Rodriguez NR. Metabolic response to provision of mixed protein-carbohydrate supplementation during endurance exercise. Int J Sport Nutr Exerc Metab. 2002; 12(4):384-97.

30. Ivy JL, Goforth HW, Damon BW, McCauley TR, Parsons EC, Price TB. Early postexercise muscle glycogen recovery is enhanced with a carbohydrateprotein supplement. J Appl Physiol. 2002; 93(4):1337-44. doi: 10.1152/japplphysiol.00394

31. Ivy JL, Res PT, Sprague RC, Widzer MO. Effect of a carbohydrate-protein supplement on endurance performance during exercise of varying intensity. Int J Sport Nutr Exerc Metab. 2003; 13(3):382-95.

32. Williams AG, Oord M, Sharma A, Jones DA. Is glucose/amino acid supplementation after exercise an aid to strength traning. Br J Sports Med. 2001; 35(2):109-13. doi: 10.1136/bjsm.35.2.109

33. Howarth KR, Moreau NA, Phillips SM, Gibala MJ. Coingestion of protein with carbohydrate during recovery from endurance exercise stimulates skeletal muscle protein synthesis in humans. J Appl Physiol. 2009; 106(4):1394-402. doi: 10.1152/japplphysiol. 90333

34. Toone RJ, Betts JA. Isocaloric carbohydrate versus carbohydrate-protein ingestion and cycling time- 
trial performance. Int J Sport Nutr Exerc Metab. 2010; 20(1):34-43.

35. Saunders MJ. Coingestion of carbohydrate-protein during endurance exercise: Influence on performance and recovery. Int J Sport Nutr Exerc Metab. 2007; 17:S87-103.

36. Currell K, Jeukendrup AE. Validity, reliability and sensitivity of measures of sporting performance. Sports Med. 2008; 38(4):297-316.

37. Hartman JW, Tang JE, Wikinson SB, Tarnopolsky MA, Lawrence RL, Fullerton AV, et al. Consumption of fat-free fluid milk after resistance exercise promotes greater lean mass accretion than does consumption of soy or carbohydrate in young, novice, male weighlifters. Am J Clin Nutr. 2007; 86(2):373-81.

38. Wilkinson SB, Tarnopolsky MA, Macdonald MJ, Macdonald JR, Armstrong D, Phillips SM. Consumption of fluid milk promotes greater muscle protein accretion after resistance exercise than does comsumption of an isonitrogenous and isoenergetic soy-protein beverage. Am J Clin Nutr. 2007; 85(4):1031-40.
Received on: 2/28/2013

Final version on: 4/30/2014

Approved on: 5/19/2014 
